\title{
FENOMENA WARIA DAN DAMPAK JANGKA PANJANG GANGGUAN PSIKIS KORBAN KEKERASAN SEKSUAL ANAK
}

\author{
OLEH: \\ ALI AR-RIDHO ${ }^{1}$, MEILANNY BUDIARTI S. ${ }^{2}$, SAHADI HUMAEDI ${ }^{3}$, HETTY KRISNANI ${ }^{4}$ \\ 1. Mahasiswa Program Studi Sarjana (S-1) Ilmu Kesejahteraan Sosial, Fakultas IImu Sosial dan IImu Politik Universitas Padjadjaran \\ 2. Pusat Studi Kesejahteraan Anak dan Keluarga Fakultas IImu Sosial dan IImu Politik Universitas Padjadjaran \\ 3. Pusat Studi Kewirausahaan Sosial, CSR, dan Pengembangan Masyarakat Fakultas IImu Sosial dan Ilmu Politik Universitas \\ Padjadjaran \\ 4. Pusat Studi Kesejahteraan Anak dan Keluarga Fakultas IImu Sosial dan IImu Politik Universitas Padjadjaran
}

Email:

ridhoolife@gmail.com¹,meilannybudiarti13@gmail.com2,sahadi.humaedi@unpad.ac.id3,hettykrisnani@yahoo.com4

\begin{abstract}
ABSTRAK
Fenomena waria masih merupakan masalah yang belum mendapatkan perhatian khusus dari masyarakat. Permasalahan mereka belum mendapatkan urgensi intervensi baik dari kalangan akademisi maupun profesional. Fenomena ini juga masih banyak meninggalkan tanya Tanya besar di dalam masyarakat, yaitu terkait sebab dari permasalahan yang mereka hadapi. Terdapat banyak dimensi yang dapat dikaji untuk menjelaskan fenomena ini salah satunya dengan menggunakan kajian konstruksi emosional dalam ilmu psikologi yang menjelaskan tentang terbentuknya proses mental seseorang berdasarkan memori masa lalu. Dalam tulisan ini penulis menggunakan pendekatan kajian konstruksi emosional tersebut untuk mengurai sebab dan akar permasalaha waria yang kemudian dari kajian tersebut dapat ditentukan metode untuk mencegah dan mengintervensi permasalahan waria.
\end{abstract}

Kata kunci: Waria, Konstruksi emosional, intervensi, pencegahan

\section{ABSTRACT}

The phenomenon of transvestites is still a problem that has not received special attention from the community. Their problems have not gained the urgency of intervention either from academics or professionals. This phenomenon also still leaves a lot of questions asked in the community, which is related to the causes of the problems they face. There are many dimensions that can be studied to explain this phenomenon one of them by using the study of emotional construction in psychology that explains the formation of mental processes of a person based on past memory. In this paper the authors use the approach to the study of emotional construction to unravel the causes and roots of transvestite problems which then from the study can be determined methods to prevent and intervene transvestite problems.

Keywords: Transvestite, Emotional construction, intervention, prevention 


\section{Pendahuluan}

Kasus kekerasan seksual pada anak terus mengalami peningkatan pada setiap tahunnya. Dilansir dari data yang diterbitkan oleh Komisi Perlindungan Anak Indonesia yang mencatat telah terjadi peningkatan kasus kekerasan seksual pada anak sebanyak $100 \%$ di rentang tahun 2013 - 2014 dan angka ini terus bertambah pada setiap tahunnya. Dengan merujuk pada data tersebut, muncul banyak kekhawatiran publik terkait dampak psikis negatif yang fatal yang sangat dimungkinkan akan terjadi pada korban kekerasan seksual anak. Terdapat banyak dampak psikologis negatif yang dapat terjadi pada anak yang menjadi korban kekerasan seksual salah satu dampak paling berbahaya adalah terjadinya penyimpangan orientasi seksual yang kemudian menjadikan seseorang memiliki kecenderungan untuk menjadi lesbian, gay, biseksual dan transgender (LGBT).

Perubahan orientasi seksual ini merupakan dampak negatif yang terjadi dan memiliki fase rentang terjadinya relatif lama, bahkan dampak negatif ini bisa terjadi setelah bertahun-tahun dari peristiwa kekerasan seksual yang dialami oleh korban. Namun demikian, dampak negatif ini sangat melekat pada diri korban dan cenderung sangat sulit untuk dirubah, sehingga perlu mendapatkan perhatian dan penanganan khusus baik itu dalam proses pencegahan maupun dalam proses intervensinya. Bahkan pada saat proses identifikasi terhadap gejala-gejala seseorang mulai memiliki kecenderungan orientasi seksual yang menyimpang pun, sedapat mungkin dilakukan dengan seksama dan serius agar tidak berlanjut menjadi penyimpangan orientasi seksual.

\section{Metode}

Metode yang digunakan dalam penelitian ini adalah metode deskriptif dengan pendekatan kualitatif, yaitu agar diperoleh data yang spesifik, lengkap, dan mendalam tentang subyek dan obyek penelitian dari berbagai perspektif yang terkait, sehingga dapat dipaparkan gambaran situasi dan kondisi di lapangan sebagai bahan analisis untuk diambil simpulan.

Sumber data dalam penelitian ini terdiri dari sumber data primer dan sumber data sekunder yang diperoleh dengan menggunakan beberapa teknik pengumbulan data, yaitu wawancara secara mendalam, observasi non partisipatif dan studi kepustakaan terhadap berbagai literalur terkait dengan konteks penelitian. Untuk menjelaskan hal ini, penulis menggunakan data hasil penelitian penulis terhadap komunitas waria di bilangan Jakarta dan Bandung yang sebagian besar menjadi gay, waria dan transgender dikarenakan efek psikologis dari kekerasan seksual yang pernah mereka alami di masa anak-anak

\section{Pembahasan}

Banyak faktor yang menyebabkan seseorang mengalami penyimpangan seksual, baik itu faktor yang berasal dari dalam diri mereka sendiri (faktor internal) maupun faktor-faktor yang berasal dari luar diri mereka (faktor eksternal). Dalam penelitian ini, fenomena yang dikaji adalah kasus penyimpangan seksual yang diakibatkan oleh faktor eksternal, yaitu akibat dari kekerasan seksual pada anak hingga menyebabkan korban mengalami gangguan psikis dan memilih untuk menjadi seorang waria.

Seorang korban kekerasan seksual pada saat anak-anak hingga kemudian memilih untuk menjadi seorang waria tentunya mengalami gangguan mental health dalam dirinya. Hal ini ditandai dengan beberapa gejalan sebagai berikut:

1. Kesulitan menerima orientasi seksual mereka, kemudian beralih ke minum alkohol dan obat-obatan terlarang

2. Mencoba untuk merahasiakan orentasi seksual mereka dengan berbohong dan berpura-pura

3. Merasa rendah diri 


\begin{tabular}{|l|l|l|l|l|}
\hline Jurnal Penelitian \& PKM & Juli 2017 & Vol 4, No: 2 & Hal: $129-389$ & ISSN \\
\hline
\end{tabular}

4. Memiliki resiko tinggi untuk menyakiti diri sendiri dan bunuh diri

5. Kerusakan hubungan atau kurangnya dukungan dari keluarga atau orangorang terdekat

6. Post-tarumatic stress disorde dan depresi sebagai efek dari bullying yang berkepanjangan.

Berbagai situasi tersebut di atas, tergambar dalam pemaparan hasil penelitian yang telah dilakukan. Sebagian besar waria yang penulis temui mengaku bahwa pada awalnya mereka merupakan korban dari pelecahan seksual sodomi yang mereka alami ketika mereka duduk di sekolah dasar kelas 56 sekolah dasar yang dilakukan oleh orangorang terdekatnya salah satunya tetangga mereka dan terjadi secara berulang. Mereka mengaku mengalami trauma luar biasa dan tidak bisa berbuat banyak untuk membela diri mereka sendiri atau bahkan hanya sekedar untuk mengadukannya kepada keluarga mereka. Seiring waktu berjalan, kasus pelecehan ini terjadi berulang sampai mereka merasa 'terbiasa' dengan apa yang mereka alami.

Namun tanpa sadar mereka mulai menyadari bahwa mereka mulai menyukai teman laki-laki yang mereka tidak tahu apa sebabnya, mereka menyadari bahwa hal tersebut merupakan hal yang salah namun karena mereka tak mengetahui sebab dan tidak bisa menceritakan apa yang mereka alami sehingga mereka hanya menyimpan apa yang mereka alami sendiri hingga pada akhirnya mereka merasa adalah wanita yang 'terjebak' dalam tubuh laki-laki dan memutuskan untuk menjadi 'diri sendiri' yaitu sebagai waria dan mulai menjalin hubungan dengan laki-laki.

Fase perubahan mereka merubah diri menjadi waria pun memakan waktu yang tidak sebentar, mereka menuturkan pergolakan batin yang mereka rasakan ketika mereka memutuskan untuk merubah kepribadian diikuti oleh gejolak psikis dan perlawanan dan rasa tidak terima mengapa mereka bisa menyukai pria, namun kembali mereka tidak bisa berbuat banyak untuk menolong diri mereka sendiri sehingga akhirnya mereka pasrah akan kondisi yang mereka miliki.

Hubungan sebab akibat berubahnya orientasi seksual pada anak laki-laki yang selanjutnya membentuk anak tersebut menjadi gay/waria dapat dijelaskan menggunakan teori psikologi, khususnya dalam kajian konstruksi emosional dan proses kognitif behavioural. Dalam kajian konstruksi emosional dijelaskan bahwa setiap kejadian meninggalkan jejak emosi pada setiap orang yang selanjutnya memiliki dampak kognitif behavioural yang membentuk pola pikir dan kebiasaan yang selanjutnya dalam jangka panjang akan membentuk kepribadian seseorang.

Dalam konteks kasus waria ini, meskipun mereka mengakui memiliki trauma yang mendalam pada saat pertama kali mengalami kekerasan seksual, namun trauma ini justru menjadi salah satu trigger dalam konstruksi emosional yang menyebabkan mereka memiliki ketertarikan pada pria dikarenakan kekerasan seksual yang terjadi berulang membuat mereka terbiasa 'menikmati' tubuh pria dan selanjutnya memberikan pola kognitif dan efek behavioural untuk memiliki kecenderungan untuk menyukai pria.

Dijelaskan secara lebih spesifik, konstruksi emosional dari sebuah kejadian memiliki dampak yang luar biasa dan mampu untuk membentuk dan mengganti proses kognitif yang sudah ada dengan proses kognitif yang baru tergantung seberapa hebat jejak emosional yang tertinggal pada seseorang terlepas dari baik atau buruk jejak emosional yang ditinggalkan tersebut. Dalam konteks kasus waria ini kejadian kekerasan seksual yang terjadi berulang ini meninggalkan trauma dan jejak emosional yang mendalam yang mampu menggantikan proses kognitif mereka yang dahulunya menyukai wanita dengan proses kognitif yang baru yaitu menyukai pria dan proses kognitif inilah yang selanjutnya membentuk behavior yang mencerminkan gejala-gejala seseorang memiliki 
kecenderungan untuk tertarik menyukai sesama jenis.

Jika dikritisi lebih dalam, kasus berubahnya orientasi seksual pada anak lakilaki yang menjadi korban kekerasan seksual tidak selalu diikuti dengan berubahnya kepribadian menjadi wanita yang selanjutnya membentuk kepribadian mereka menjadi waria. Berubahnya kepribadian mereka menjadi waria merupakan salah satu dampak 'tambahan' yang terkait dengan masalah kenyamanan mereka dalam mengaktualisasikan identitas mereka sebagai penyuka sesama jenis.

Seperti kasus waria yang penulis temui merupakan salah satu contoh dari korban kekerasan seksual yang memilih untuk menjadi waria karena mereka merasa nyaman dengan kepribadian itu terlebih ketika menjalin hubungan dengan pria yang mampu memosisikan mereka sebagai wanita normal. Namun, tanpa disadari, berubahnya kepribadian mereka menjadi waria merupakan multiplier effect dari dampak psikis korban kekerasan seksual yang membuat dampak yang terjadi semakin lebih kompleks.

Satu hal yang perlu digarisbawahi mengenai efek psikis dari kekerasan seksual pada anak ini terlepas apapun dampak yang terlihat merupakan hasil dari berubahnya konstruksi emosional dan proses kognitif yang menyebabkan seseorang memiliki gangguan kepribadian. Perubahan konstruksi emosional dan proses kognitif inilah yang selanjutnya menjadi fokus dalam assessment dan intervensi dari dampak psikis yang dialami oleh korban kekerasan seksual anak.

Adapun langkah preventif dan kuratif yang bisa kita lakukan untuk menekan dampak negatif dari gangguan psikis yang dialami oleh korban kekerasan seksual anak yang telah terdeteksi adalah dengan mengenali gejalagejala kelainan emosional dan kognitif dan selanjutnya memberikan terapi emotional healing dan terapi kognitif untuk menghindari dampak yang lebih buruk dan salah satunya adalah berubahnya konstruksi emosional dan proses kognitif anak yang menjadi korban kekerasan seksual mengalami gangguan psikis dan perubahan kepribadian di masa remaja dan dewasanya.

Terapi emotional healing merupakan salah satu terapi yang membantu seorang yang memiliki kesulitan emosional untuk melepaskan emosi yang tidak bisa diungkapkan dan mampu memaafkan masa lalu yang telah terjadi dan terapi kognitif merupakan salah satu terapi yang berfokus pada perbaikan pola berfikir seseorang yang mengalami gangguan yang berdampak pada pola perilaku yang selanjutnya membentuk perilaku bermasalah. Dua terapi ini dapat diterapkan bagi anak yang menjadi korban kekerasan seksual untuk menekan dampak psikis yang dialami oleh mereka dan menghindarkan diri mereka untuk menjadi pelaku kekerasan seksual, gay dan waria di masa mendatang.

\section{Simpulan}

Permaslahan waria merupakan masalah yang sangat kompeks yang memerlukan banyak kajian dari berbagai disiplin ilmu untuk menjelaskan fenemona tersebut hingga memberikan intervensi yang tepat bagi mereka. Fenomena ini sudah saatnya mendapatkan perhatian serius dari semua kalangan masyarakat, terutama dalam segi pencegahan. Pada akhirnya, anak yang menjadi korban kekerasan seksual memiliki resiko besar yang tak terlihat yang akan muncul menjadi masalah yang kritis jika terlambat ditangani dan sudah seharusnya masalah ini menjadi perhatian bagi keluarga, akademisi, praktisi psikolog serta pekerja sosial untuk memberikan intervensi klinis sejak dini bagi anak yang menjadi korban kekerasan seksual agar mereka dapat hidup dengan mental yang sehat dan terhindar dari resiko fatal di masa dewasa mereka. 


\begin{tabular}{|c|c|c|c|c|}
\hline Jurnal Penelitian \& PKM & Juli 2017 & Vol 4, No: 2 & Hal: $129-389$ & $\begin{array}{c}\text { ISSN } \\
2442-448 X(p), 2581-1126(e)\end{array}$ \\
\hline
\end{tabular}

\section{DAFTAR PUSTAKA}

Adi, Isbandi Rukminto. 2013. Kesejahteraan Sosial (Pekerjaan Sosial,Pembangunan Sosial, dan Kajian Pembangunan). Jakarta: Rajawali Pres.

Yusrun Alamsyah, Cepi. 2015. Praktik Pekerjaan Sosial Generalis: Suatu Tuntunan Intervensi. Yogyakarta: Ikatan Pelajar

Krisnani, Hetty. 2016. Psikopatologi untuk Pekerjaan Sosial. Sumedang: Unpad Press
Raharjo, ST. 2015. Assessment untuk Praktik Pekerjaan Sosial dan Kesejahteraan Sosial. Bandung: Unpad Press 2015. Dasar Pengetahuan Pekerjaan Sosial. Bandung: Unpad Press. 2015. Keterampilan Pekerjaan Sosial: Dasar-dasar. Bandung, Unpad Press.

Richardson, Daniel C. 2014. Social Psychology for Dummies. hicester: John Willey \& Sons

Branch,Rhena.,Willson,Rob. 2010. Cognitive Behavioural Therapy 2nd edition. Chicester: John Willey \& Sons, Ltd 